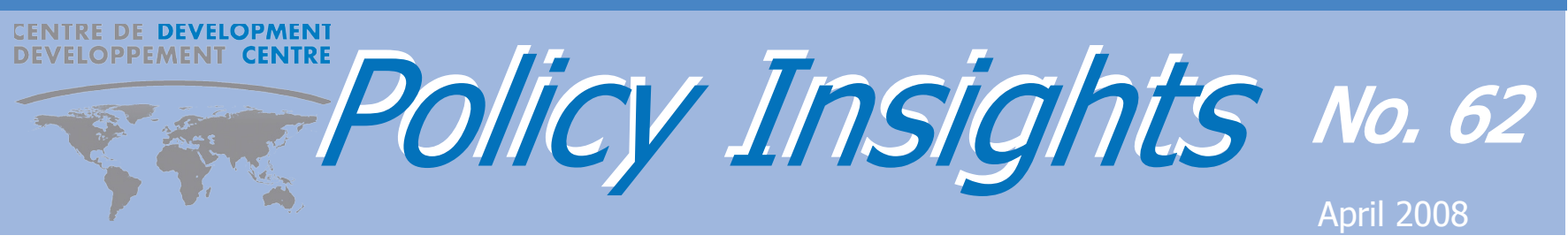

\title{
Investing in Africa's Youth
}

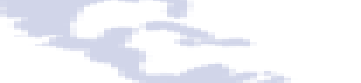

by Lucia Wegner (based on the African Economic Outlook 2008*)

- African countries face high youth unemployment and a skills shortage.

- Technical and vocational systems in Africa are poorly funded and managed.

- Skill-development strategies need to be integrated into poverty-reduction strategies and focused on sectors with promising employment prospects.

Some 133 million young people (half of Africa's young) are illiterate. Many young people have few or no skills. Over 20 per cent of young people are unemployed in subSaharan Africa. Such figures tell their own story: Africa's youth needs vocational training.

Higher technical skills are crucial for enhancing competitiveness and contributing to social inclusion, produce better employment and help reduce poverty. The 2008 African Economic Outlooks review of 35 countries, however, shows that technical and vocational skills development systems in Africa suffer from a shortage of qualified staff, obsolete equipment, ill-adapted programmes and weak links with the job market. Very few countries emphasise skills development in the informal sector, the largest employer and source of training in Africa ${ }^{1}$.

Skills can be obtained either through structured and specialised institutions or through on-the-job practical experience, or both - the so-called "dual" training. Traditional apprenticeship in the informal sector predominates: the formal system accounts for less than 5 per cent of trainees. For instance, in Senegal, some 400000 young people are in apprenticeship annually, compared to some 7000 graduates from the formal vocational training centres; and up to 80 per cent of skill development in Ghana is through the apprentice system.

Technical and vocational training systems in Africa suffer from both a lack of resources (with only 2 to 6 per cent of education budgets ), and a shift in international priorities. Donors have been uncertain allies of training. At the1990 Education for A//conference in Jomtien and the Millennium

1. The informal sector employs 95 per cent of workers in Benin, 90 per cent in Cameroon, Ethiopia and Senegal, and 31 per cent in South Africa.
Summit in 2000, primary education became the priority. One result of this has been the shift away from technical and vocational training. Now secondary and vocational schools in Mozambique and South Africa, for example, are struggling to absorb youngsters from primary school.

This increasingly dire situation has put training back on the international agenda. In response, many African countries are making progress in reforming their training systems. They tend to be most successful when there is a clear vision of the desired outcome. In particular, to have maximum effect training strategies need to be fully integrated into poverty-reduction plans and focused on sectors with promising employment prospects.

Programmes need to be flexible and responsive to the demands of the labour market, as in Ethiopia, South Africa and Mozambique, where skills shortages are specifically targeted. They need to be independently supervised by bodies like the Technical Education, Vocational and Entrepreneurship Training Authority in Zambia or the Botswana Training Authority, and they need to be monitored and evaluated for relevance and impact on the labour market.

Partnerships with enterprises, trade unions, and NGOs can help to enhance the relevance of training to the labour market. Training schools in Ethiopia, for example, encourage the participation on the non-public sector in school management, which can also be an incentive to private sources of funding. In Morocco and Ethiopia, fiscal incentives encourage enterprises to promote in-service training.

Consideration for the informal sector is essential. Traditional apprenticeships in skills found in the informal sector should be included in technical and vocational training systems 
reforms, as they are for master craftspeople in Uganda, Niger and Mali. Certification of skills acquired through traditional apprenticeship, as in the Vocational Skill Certificate in Benin, also provide a concrete link with the needs of the informal sector.

To assess the outcome of such measures, labour-market observatories in Benin and Rwanda not only monitor changes in the labour market but track the careers of graduates following training to see if they find employment or not. The generalisation of such observatories to all African countries would be a positive and significant development.

Existing or innovative employment-oriented schemes can operate as supports and complements to training. The AfDB African Women in Business Initiative (AWIB) and the ILO/AfDB Framework for Growth Oriented Women Entrepreneurs (GOWE) in Cameroon, Ethiopia, Kenya, Tanzania and Uganda are examples, but there is plenty of room for others.

African countries are diversifying funding sources for skills development and there is increased competition between public and private training providers. The state, however, retains the role of providing access to training for the poor, the disadvantaged and the vulnerable. The challenge is to develop an integrated financing framework that will ensure equitable contributions from government, local communities, industry and the beneficiary trainees.

The employment potential of the young people of Africa depends on it.

* published jointly by the African Development Bank and the OECD Development Centre with the United Nations Economic Commission for Africa with financial support from the European Commission.

Readers are encouraged to quote or reproduce material from OECD Development Centre Policy Insights for their own publications. In return, the Development Centre requests due acknowledgement and a copy of the publication. Full text of Policy Insights and more information on the Centre and its work are available on its web site: www.oecd.org/dev
OECD Development Centre 2, rue André-Pascal, 75775 Paris Cedex 16, France Tel.: +33-(0)1 45.24.82.00

Fax: +33-(0)144306149 E-mail: dev.contact@oecd.org 